\title{
Natural drying of forest biomass: Effect of stack height and cover in the province of Valdivia, Chile
}

\section{Secado natural de biomasa forestal: efecto de la altura y cobertura del apilado en la provincia de Valdivia, Chile}

\author{
Rodrigo Labbé a*, Patricio Carey a, Guillermo Trincado a, Oscar Thiers ${ }^{\text {a }}$ \\ *Corresponding author: Universidad Austral de Chile, Faculty of Forest Sciences and Natural Resources, \\ Institute of Forest and Society, Valdivia, Chile, tel.: 56-63-2293002, rodrigo.labbe@uach.cl
}

\begin{abstract}
SUMMARY
Moisture content is considered one of the most important quality parameters in wood fuels. In this context, natural drying is a cheap and easy method to reach adequate moisture content in forest biomass. The objective of this study is to evaluate the effect of different treatments feasible to be applied operationally in the natural drying of whole small trees. Whole trees from natural regeneration of Acacia melanoxylon with diameters of 3 to $12 \mathrm{~cm}$ were used in this research, in Los Ríos Region, Chile. Trees were stacked into piles outside the forest between January and December 2012, distributed in 12 biomass piles. Piles were evaluated at two heights (one and two meters), and two protection levels (without protection and using a semi-permeable cover). A factorial design with three repetitions per treatment was used. Indirect measurements of moisture content were obtained by monthly weight records. These were used to model the progress of drying in each pile. The overall effect of treatments was evaluated with factorial variance analysis using the GLM procedure. For the study conditions, results indicate that natural biomass drying has a strong seasonal component. Consequently the use of cover was essential in winter season. During summer months the cover was not necessary, being able to reach moisture content lower than $30 \%$ after the summer if storage started in the beginning of January. In this case, better results were obtained with the two-meter-high piles because they were less sensitive to occasional summer rains.
\end{abstract}

Key words: Acacia melanoxylon, wood fuel, moisture content, biomass storage.

\section{RESUMEN}

El contenido de humedad es considerado uno de los parámetros de calidad más importantes en los combustibles de madera. En este contexto, el secado natural es un método barato y fácil de aplicar. El objetivo de este estudio fue evaluar el efecto de distintos tratamientos viables de ser aplicados operacionalmente en el proceso de secado natural de biomasa forestal. Se utilizó como material de estudio árboles enteros provenientes de regeneración natural de Acacia melanoxylon con diámetros de 3 a $12 \mathrm{~cm}$, en Valdivia, región de Los Ríos, Chile. Los árboles fueron apilados fuera del dosel desde enero a diciembre de 2012, distribuidos en 12 pilas de biomasa. Se evaluó el apilado a una altura de uno y dos metros y el uso de cobertor semipermeable. Se aplicó un diseño factorial con tres repeticiones por tratamiento. Mediante registros periódicos de peso se obtuvieron mediciones indirectas de contenido de humedad. Estas mediciones fueron utilizadas para modelar el progreso de secado en cada pila. Se evaluó el efecto global de los tratamientos con análisis de varianza factorial usando el procedimiento GLM. Para las condiciones de estudio, los resultados indican que el secado natural de biomasa posee un fuerte componente estacional. Consecuentemente, el uso de cobertor fue fundamental en la época invernal. Durante los meses estivales no fue necesario, pudiendo alcanzar un contenido de humedad inferior a $30 \%$ transcurrido el verano. En este último caso, el apilado a dos metros de altura mostró ser menos sensible a periodos ocasionales de lluvias estivales.

Palabras clave: Acacia melanoxylon, contenido de humedad, árboles enteros, biocombustible, almacenamiento de biomasa.

\section{INTRODUCTION}

Research on methods of producing high quality wood chips will be increasingly important for an emerging bioenergy sector with important development potential in south-central Chile, mainly due to the high availability of forest biomass. High-quality wood fuel ensures efficient boiler operation, minimizing maintenance costs (Röser et al. 2011). In this sense, moisture content is considered one of the most important quality parameters in wood fuels (Alakangas and Virkkunen 2007, Marcoullier and Anderson 1989, Richardson et al. 2002, Röser et al. 2011). Water contained in freshly cut trees is a significant part of the total weight, increasing the transport cost, reducing net energy content and increasing the level of pollutant emissions during combustion, as breathable particulate material, 
carbon dioxide $\left(\mathrm{CO}_{2}\right)$ and nitrogen oxides $\left(\mathrm{NO}_{\mathrm{x}}\right)$ (Kofman and Kent 2009a, Brand et al. 2011).

Thermal drying energy costs are an important part of the financial burdens facing the wood industry. Heat requirement of the conventional wood drying system includes not only the warming and heat used for evaporation of water, but also the expense of warming up wood, and amounts of about 0.8 to $1.1 \mathrm{kWh} \mathrm{kg}^{-1}$ of water that is removed from wood (Kaltschmitt 2016, Ananias et al. 2012). Natural drying is based on taking advantage of favorable environmental conditions to reduce the water of forest biomass and, therefore, does not require any investment in storage. Although there is a cost associated with immobilized capital, the developed heating markets consider differentiated prices of wood fuel, according to their moisture content (Egger et al. 2012), with which the opportunity cost associated with immobilized capital is offset. Natural drying can be carried out after harvest and before chipping, to reduce the moisture content of biomass to less than $30 \%$ (wet basis), which makes it suitable for the supply of CHP plants (>5 MW), and also for the supply of district heating systems and/or central heating systems $(<5 \mathrm{MW})$ (Alakangas and Virkkunen 2007, Palmer et al. 2011).

This biomass harvesting method is popular in Europe and is called "two-pass method", which consists in cutting biomass, ordering it in piles and afterwards picking it up and chipping it at the same time (Kofman and Kent 2009a, Pari et al. 2013). During the planning of this process, a series of factors influence the speed of drying such as climatic conditions, the season of the year, forest species, biomass composition and size of the piece (Kofman and Kent 2009abc, Brand et al. 2011, Filbakk et al. 2011, Pari et al. 2013, Wetzel et al. 2017). Also covering is feasible, although the extent of its effect depends on the climatic conditions at the storage location (Erber and Kühmaier 2017). A study of natural drying that covers different countries in Europe in whole trees of coniferous and broadleaf with diameters from two to more than 25 centimeters and a wide range of heights concludes that the use of cover is of paramount importance in climates characterized by high rainfall (Röser et al. 2011). On the other hand, through connected studies focused on the harvest, it was observed that oxen used for skidding present difficulties to stack biomass at a height over 1.5 meters; in contrast, a farm tractor with grapple has the ability to concentrate biomass in stacks of up to three meters high.

The present study is inserted in the evaluation of the use of mixed plantation systems for simultaneous forest and wood energy production (Fondef B09I1007 project), and is focused on the natural drying process, as an intermediate stage between harvest and chipping of forest biomass, in a context of wood fuel supply for central heating systems, district heating systems and CHP plants in southcentral Chile. The forest biomass used in this study corresponds to natural regeneration of Acacia melanoxylon R. Br. under the cover of a plantation of Eucalyptus glo- bulus Labill., established in 2004 in Valdivia, region of Los Ríos, Chile.

The hypothesis of this research is that it is possible to implement a natural drying process after harvesting and before chipping forest biomass, and reach a moisture content under $30 \%$ (wet basis) in one year of exposition, under the environmental condition of the province of Valdivia. The objective of the study was to evaluate the effect of different treatments, which can be applied operationally, over drying speed and over the capacity to obtain a moisture content of biomass piles outside the forest cover (for example stacked at roadside), acceptable for use as wood fuel $(<30 \%$ wet basis) during one year of exposure.

\section{METHODS}

Study area. The study was carried out in Las Palmas $\left(39^{\circ} 44^{\prime} 50^{\prime \prime} \mathrm{S}-73^{\circ} 08^{\prime} 50^{\prime \prime} \mathrm{O}\right)$, a property of Universidad Austral de Chile. Las Palmas is located $20 \mathrm{~km}$ north of Valdivia City, Los Rios Region, Chile. The climate is temperate rainy with Mediterranean influence. The average annual temperature was $11.6^{\circ} \mathrm{C}$, with a monthly mean maximum of $15.9^{\circ} \mathrm{C}$ in January and a minimum of $5.6^{\circ} \mathrm{C}$ in July (Donoso et al. 2008). During the study conducted in 2012 the annual precipitation rose to $1,919 \mathrm{~mm}$ concentrated in winter months and with occasional periods of drought in summer (figure 1).

The drying study was performed in a stand characterized by high density of natural regeneration of $A$. melanoxylon, about 6,900 trees $\mathrm{ha}^{-1}$, with diameter at breast height (DBH) of 3 to 12 centimeters, with an average of

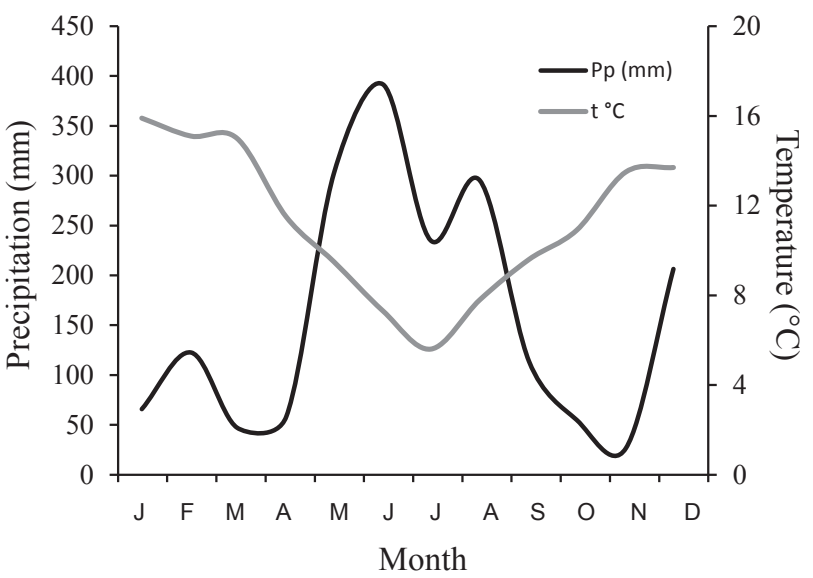

Figure 1. Fluctuation in temperature and rainfall (monthly mean) during the study. Santa Rosa Experimental Weather Station data (39 45'30' $\mathrm{S}-73^{\circ} 14^{\prime} 55^{\prime \prime} \mathrm{O}$ ), Universidad Austral de Chile (year 2012).

Fluctuación de la temperatura y precipitaciones (media mensual) durante el estudio. Datos de la Estación meteorológica Fundo Experimental Santa Rosa $\left(39^{\circ} 45^{\prime} 30^{\prime \prime} \mathrm{S}-73^{\circ} 14^{\prime} 55^{\prime \prime} \mathrm{O}\right)$, Universidad Austral de Chile (año 2012). 
$5.5 \mathrm{~cm}$, and a height of 8 to $15 \mathrm{~m}$ with an average of $10 \mathrm{~m}$, under the cover of an E. globulus plantation established in 2004. Biomass was obtained from four plots of $100 \mathrm{~m}^{2}$ each. From each plot, the whole aerial biomass of $A$. melanoxylon was extracted. Whole trees were afterward transported by oxen to the study area located within the stand in a clearing of crop residues and outside the cover of trees; stumps were lowered and the location of the biomass piles was defined by wooden stakes (figure 2). These activities were conducted between January 2 and 5, and the cover was installed in the selected piles on January 9, 2012.

Experimental design. The trial considered, as study factors, the pile height of biomass and the use of semi-permeable cover. A factorial design with two factors and three replicates per treatment was used. Piles were evaluated at two heights (one and two meters), and two protection levels (without protection and using a semi-permeable cover), with which four treatments were obtained: treatment 1) pile height of $1 \mathrm{~m}$ and with cover; treatment 2) pile height of $2 \mathrm{~m}$ and with cover; treatment 3 ) pile height of 1 $\mathrm{m}$ and without cover; and treatment 4) pile height of $2 \mathrm{~m}$ and without cover. Twelve piles of biomass were installed. Whole trees were cut into 1-meter-long pieces. The piles were distributed in four rows, each with three biomass piles. A distance of two meters between rows and a distance of one meter inside the row were used. The location of the treatments within the trial was defined in two stages. First the biomass piles were placed according to their height, aiming for a homogeneous distribution within the trial. Two rows of three biomass piles were distributed for each stacking height, one in the central part and one in the peripheral part of the trial. Subsequently, biomass piles with and without cover were randomly chosen. Particular care was taken to place each whole tree in the same biomass pile to maintain a similar proportion of stem, branches and leaves (figure 2). The material used as cover was Tyvek, which has properties of mechanical resistance, has a semi-permeable water repellent membrane allowing water vapor to pass through it, withstands temperature variations and is not degraded by attack of fungi and insects (Rabe 2003).

Measurements. The trial was evaluated for a period of one year, from January to December 2012. The first measurement was on January 5 , immediately after being filled with biomass. Piles were weighed eight times between January and the beginning of April. Of these eight measurements, six were made between February and March. From the beginning of April to December, measurements were made at an interval of approximately 30 days. The last measurement was conducted on December 29. Because it is difficult to measure the continuous loss of moisture content by direct means, since the extraction of samples to obtain intermediate readings involves disassembly and reconstruction of the pile, which is impractical, it was decided to measure the loss of moisture content indirectly, by measuring the weight loss of the pile (Kofman and Kent 2009a, Nord-Larsen et al. 2011). Weighing stack piles provided the most accurate form of continuous data, although it does not allow for within-piles conditions evaluation and usually is limited to small pile structures (Kizha and Han 2017). In biomass piles of one meter in height, the initial weight varied from 207 to $294 \mathrm{~kg}$ with an average of $240 \mathrm{~kg}$; in the piles of two meters of height, the weight oscillated between 364 and $511 \mathrm{~kg}$, with an average of $457 \mathrm{~kg}$. The Digital Hanging Balance had an accuracy of $0.1 \mathrm{~kg}$ and was attached to a mechanical hoist mounted on a wooden frame (figure 3).
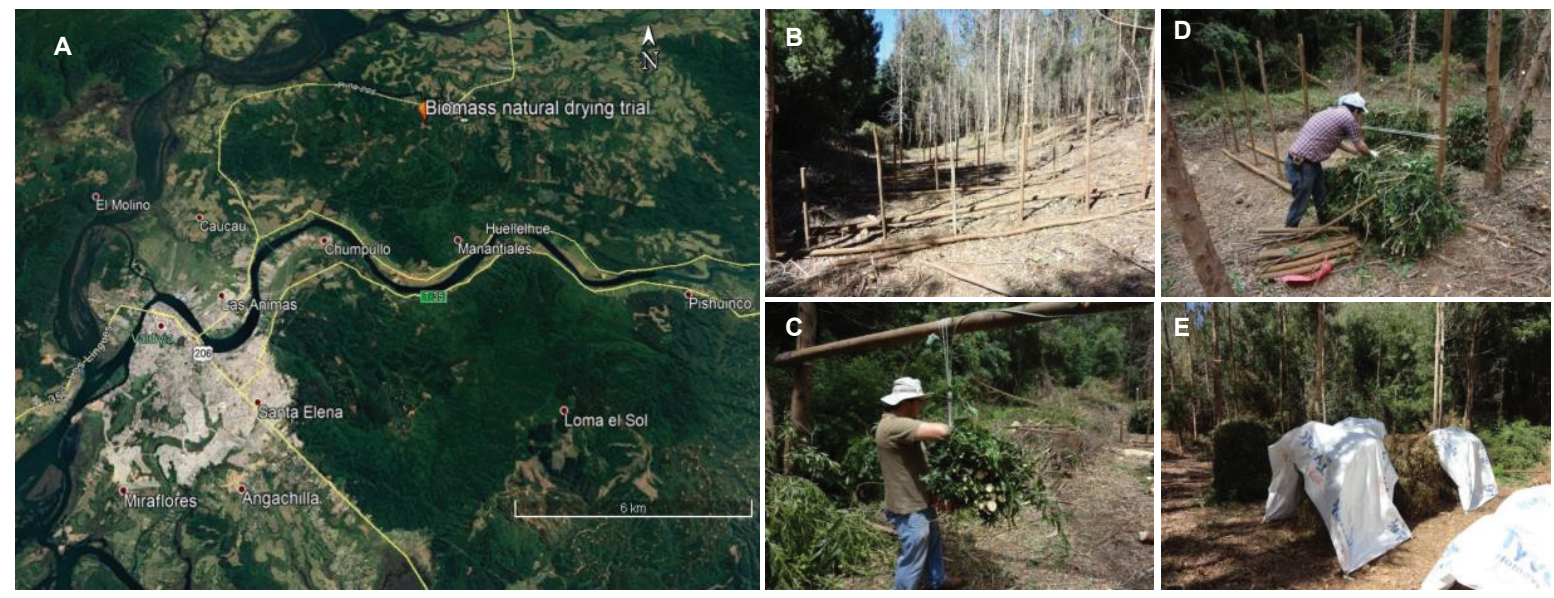

Figure 2. Natural biomass drying test: A) location of the study; B) delimitation of the trial with stakes; C) biomass weight; D) building of piles; E) biomass piles with and without cover.

Ensayo de secado natural de biomasa: A) ubicación del ensayo; B) delimitación de las pilas con estacas; C) pesado de la biomasa; D) construcción de pilas; E) pilas de biomasa con cobertor. 


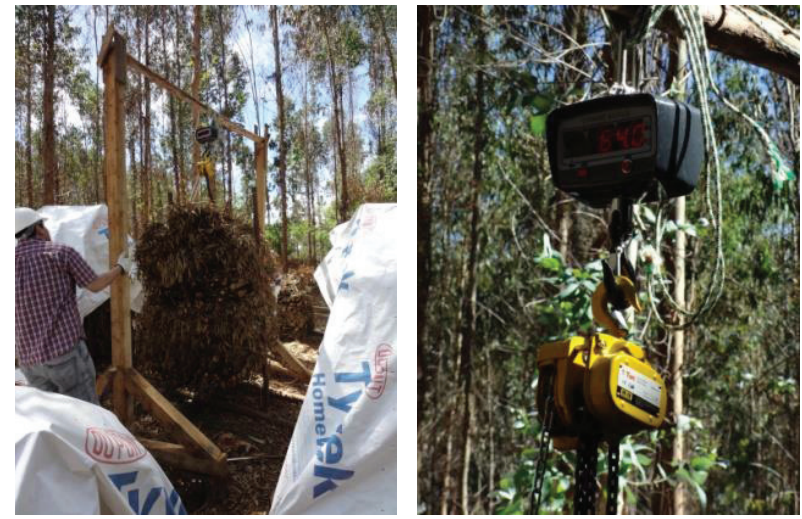

Figure 3. Record of weight in biomass piles. Registro de peso en pilas de biomasa.

Moisture content was calculated in wet basis. To establish the initial moisture content of each pile, three random samples of approximately $300 \mathrm{~g}$ were taken. This material was carefully mixed and three new samples were taken. Their moisture content in the laboratory was determined by the oven dry method according to the Chilean Standard NCH 176/1. Subsequently, the moisture content of biomass was calculated for each pile with the formula [1] adapted from Nord-Larsen et al. (2011).

$$
\mathrm{MC}_{\mathrm{t}}=\frac{\mathrm{W}_{\mathrm{t}} \times \mathrm{MC}_{0}}{\mathrm{~W}_{0}} \times 100
$$

Where:

$\mathrm{MC}_{\mathrm{t}}=$ moisture content as a percentage of total weight at time t.

$\mathrm{t}=$ time (days after the start of the trial).

$\mathrm{W}_{\mathrm{t}}=$ weight of the biomass pile in kilogram at time $\mathrm{t}$.

$\mathrm{MC}_{0}=$ moisture content as percentage of total weight at the baseline of the trial.

$\mathrm{W}_{0}$ = weight of the biomass pile in kilogram at the start of the trial.

Data analyses. Indirect moisture measurements were used to analyze the drying progress in each pile. The resulting drying curves were first evaluated qualitatively by observing changes in the moisture content of the piles. The overall effect of treatments applied during the study was assessed by Factorial Analysis of Variance using the GLM procedure [2]. This analysis was applied for data recorded after the summer season (3 April 2012), after the winter season (1 October 2012) and after the spring season (30 November 2012).

$$
\gamma_{\mathrm{ijk}}=\mu+\alpha_{\mathrm{i}}+\beta_{\mathrm{j}}+(\alpha \beta)_{\mathrm{ij}}+\varepsilon_{i \mathrm{jk}}
$$

Where:

$\mu \quad=$ average moisture content $\left(\mathrm{g} \mathrm{kg}^{-1}\right.$ total weight $)$. $\alpha_{i}=$ stack height factor.

$\beta_{j}=$ use of cover factor.

$(\alpha \beta)_{i j}=$ interaction between stack height factor and use of cover factor.

$\varepsilon_{i j k}=$ experimental error.

All analyses were done with the $\mathrm{R}$ statistics program (R Core Team 2013). In all cases the assumption of normality, homoscedasticity and residual independence were verified.

\section{RESULTS}

The initial moisture content of biomass ( 5 January 2012 ) was $42.8 \% \pm 2.5 \%$ (mean \pm standard deviation). In the measurement conducted on February 2, the moisture content of the piles was reduced until reaching an average of $30.8 \% \pm 1.7 \%$ ( \pm standard deviation). At treatments level, in the same date, the treatment with one-meter and nocover piles (T3) had higher moisture content, reaching an average of $33.3 \% \pm 1 \%$. This measurement coincides with two rainy days occurred on January 29 and 30 (figure 4). In the next measurement, made on February 14, after a period of 12 days without precipitation, all treatments reached similar moisture content, with an average of $27.6 \% \pm 1.3 \%$. However, after the rainiest day of summer (February 17), moisture content in T3 biomass piles was again comparatively higher than that presented by other treatments in the measurement made on February 21. These differences were maintained until the end of summer, due to the extent of days with precipitation, even if they are of low intensity (figure 4). At the end of the summer, on April 3, moisture content reached by T3 biomass piles was in average $28.4 \% \pm 1.2 \%$. All other treatments achieved a higher drying progress, reaching moisture content at the end of the summer of $25.6 \% \pm 0.76 \%$.

At the end of the summer, there were no significant differences in moisture content among treatments with and without cover $(P=0.051)$; while pile height did have a significant influence on the moisture content $(P=0.013)$. This difference can be explained by the better results obtained in the two-meter-high pile (figure 5).

Subsequently, the moisture content of the uncovered piles exhibited seasonal variations with high moisture content during the winter, surpassing even the initial level in the piles of a meter of height, and was decreasing during the spring. In return, the seasonal variation was less pronounced in piles with cover (figure 6). This caused highly significant differences $(P<0.0001)$ in moisture content in the piles with and without cover at the end of winter and also at the end of spring. The height of the pile also influenced significantly $(P<0.0001)$ in moisture content in these periods. This influence was again accentuated in biomass piles without cover, showing better results with the piles at a height of two meters (figure 5). On the contrary, with cover, the moisture content in the two-meter- 
high piles showed greater variation and with tendency to increase during the winter, nevertheless, during the spring, moisture content reached levels similar to those shown by the piles of one meter of height.
In the last measurement, obtained practically one year since the start of the trial, on December 29, all piles of biomass with cover reached a moisture content under $25 \%$ (or $250 \mathrm{~g} \mathrm{~kg}^{-1}$ ), independent of stacking height (figure 6).

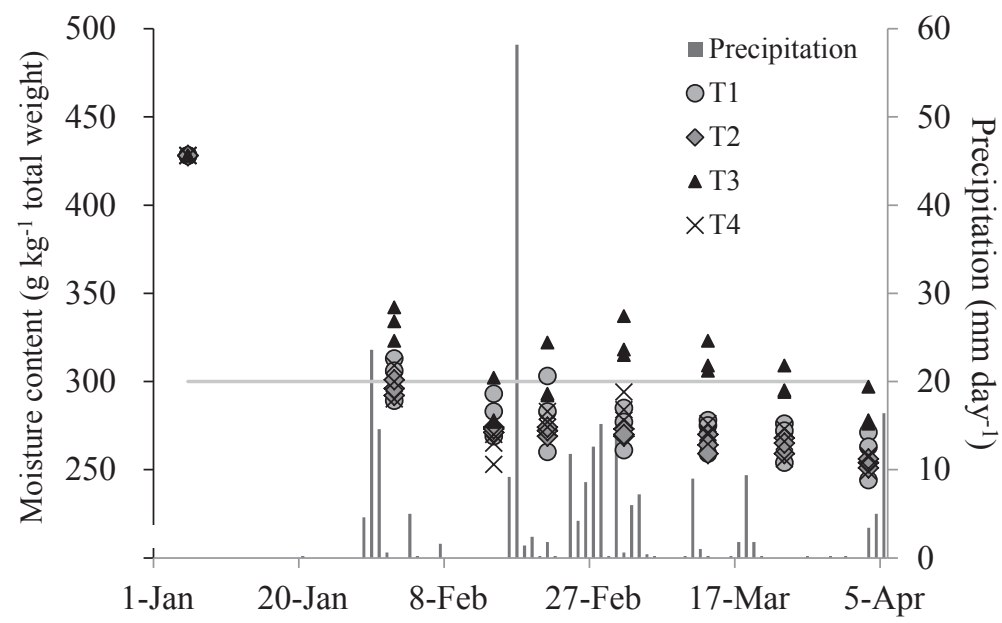

Figure 4. Relationship of natural drying progresses in forest biomass and the daily precipitations during summer season. Horizontal line represents the moisture content of $300 \mathrm{~g} \mathrm{~kg}^{-1}$ of total weight. Treatments: T1 = one-meter-high piles with cover; T2 = two-meter-high piles with cover; $\mathrm{T} 3=$ one-meter-high piles without cover; $\mathrm{T} 4=$ two-meter-high piles without cover. Three replicates are shown for each

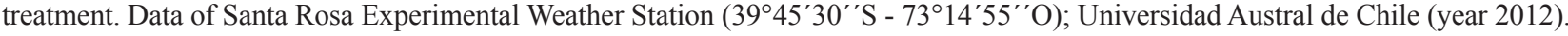

Relación entre el progreso de secado de la biomasa y la precipitación diaria durante el verano. Línea horizontal representa el contenido de humedad de $300 \mathrm{~g} \mathrm{~kg}^{-1}$ del peso total. Tratamientos: T1 = pilas de un metro de alto con cobertor; T2 = pilas de dos metros de alto con cobertor; T3 = pilas de un metro de alto sin cobertor; T4 = pilas de dos metros de alto sin cobertor. Para cada tratamiento se muestran sus tres repeticiones. Datos de precipitaciones provenientes de la Estación meteorológica Fundo Experimental Santa Rosa (3945'30' 'S - 73¹4'55' O), Universidad Austral de Chile (año 2012).
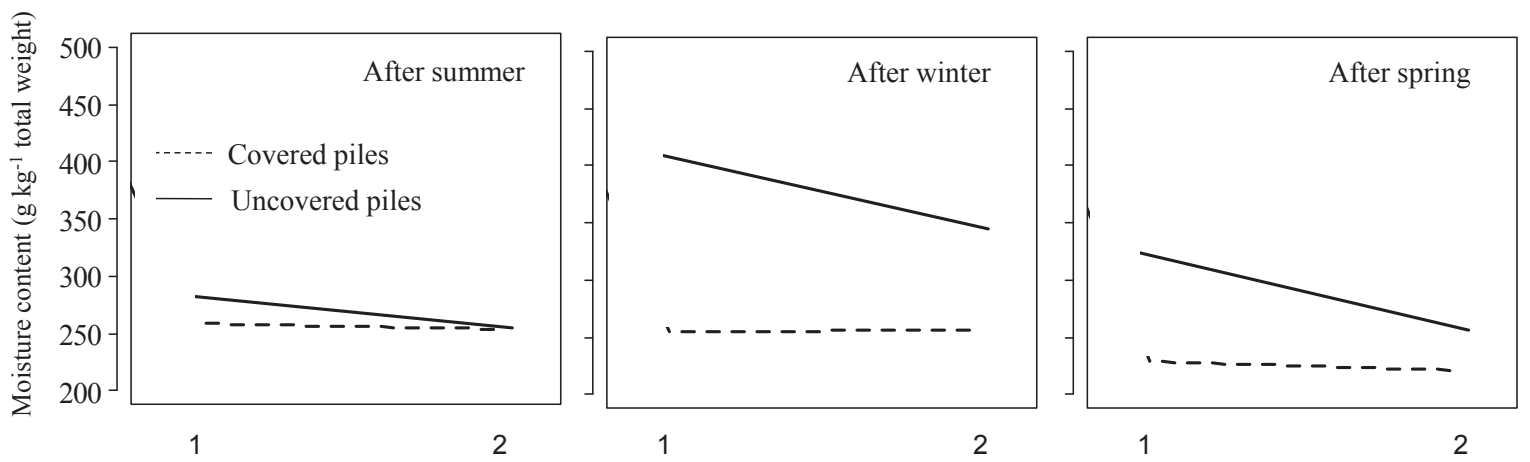

\begin{tabular}{|c|c|c|c|}
\hline Factors & After summer & After winter & After spring \\
\hline Height of the piles $(P)$ & $0.0131 *$ & $<0.0001 * * *$ & $<0.0001 * * *$ \\
\hline Use of cover $(P)$ & $0.0508 \mathrm{~ns}$ & $<0.0001 * * *$ & $<0.0001 * * *$ \\
\hline Height of the piles $\times$ Use of cover $(P)$ & $0.0650 \mathrm{~ns}$ & $<0.0001 * * *$ & $<0.0001 * * *$ \\
\hline
\end{tabular}

Figure 5. Interaction of average moisture content for each combination of pile height and use of cover. Beginning of the trial: January 5, 2012; after summer: April 3, 2012; after winter: October 1, 2012; after spring: November 30, 2012. P: Limit of probabilities in ANOVA with two factors. ***: $P<0.001 ; *: P<0.05$; ns: not significant.

Interacción de los promedios de contenido de humedad para cada combinación de altura de pila y uso de cobertor. Inicio del ensayo: 5-012012; después del verano: 03-04-2012; después de invierno: 01-10-2012; después de primavera: 30-11-2012. P: Probabilidades límites en ANDEVA con dos factores. ***: $P<0,001 ; *: P<0,05$; ns: no significativo. 


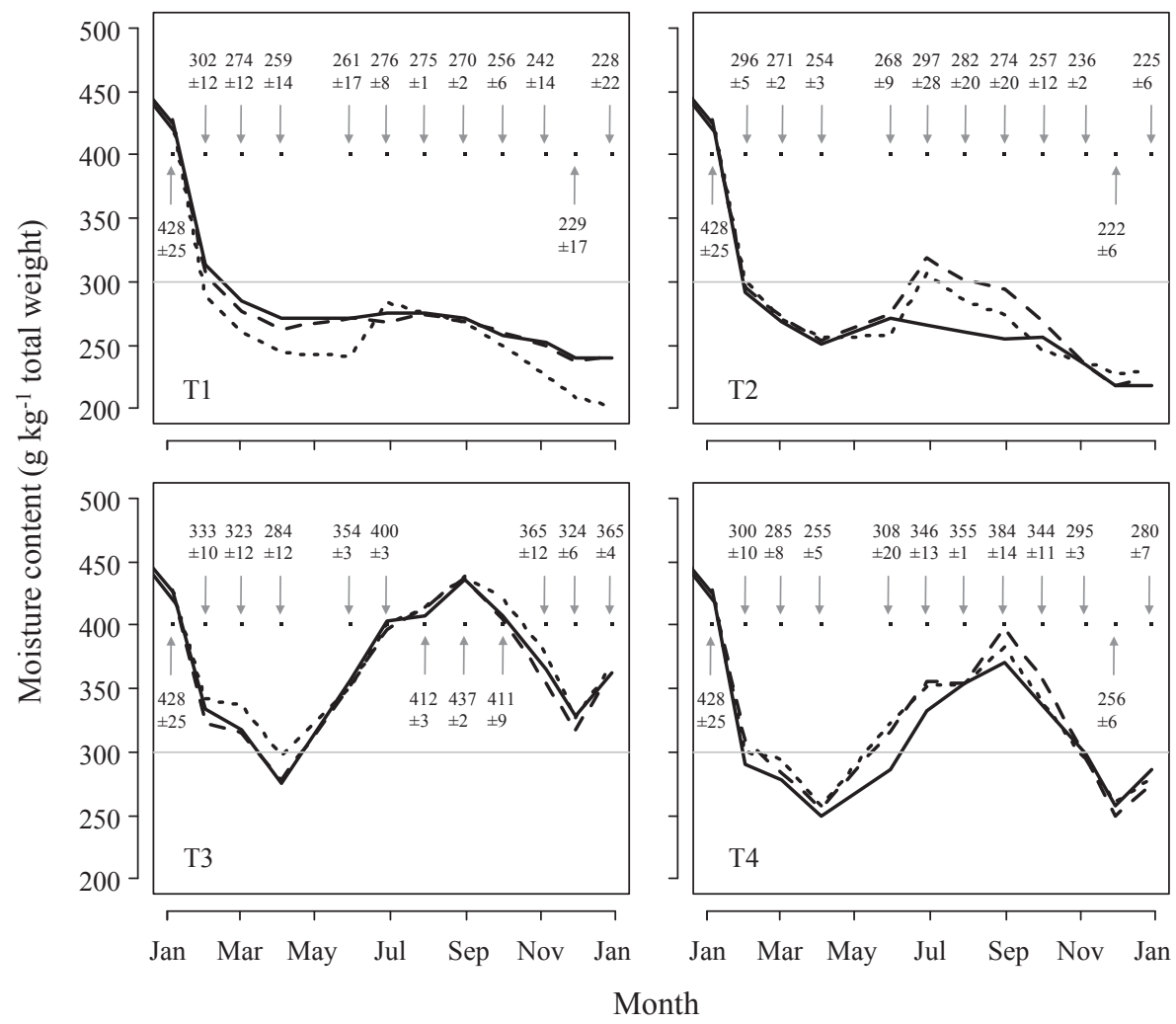

Figure 6. Relationship between time and moisture content for different biomass piles. Treatments: $\mathrm{T} 1=$ one-meter-high piles with cover; $\mathrm{T} 2$ = two-meter-high piles with cover; $\mathrm{T} 3$ = one-meter-high piles without cover; $\mathrm{T} 4$ = two-meter-high piles without cover. For each treatment, three replicates are shown. Horizontal line represents the moisture content of $300 \mathrm{~g} \mathrm{~kg}^{-1}$ of total weight. The points on the curves indicate the date of recording of pile weight and the arrows indicate moisture content (average \pm standard deviation in $\mathrm{g} \mathrm{kg}^{-1}$ of the total weight).

Relación entre el tiempo y el contenido de humedad para las diferentes pilas de biomasa. Tratamientos: T1 = pilas de un metro de alto con cobertor; $\mathrm{T} 2$ = pilas de dos metros de alto con cobertor; T3 = pilas de un metro de alto sin cobertor; T4 = pilas de dos metros de alto sin cobertor. Para cada tratamiento se muestran sus tres repeticiones. Línea horizontal representa el contenido de humedad de $300 \mathrm{~g} \mathrm{~kg}^{-1}$ del peso total. Los puntos sobre

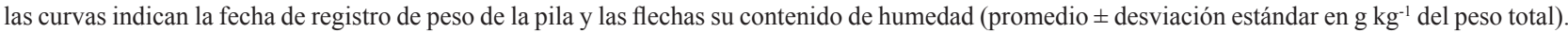

Without cover, the stacking height had an important influence on the moisture content of the biomass, which explains the highly significant interaction between both variables $(P<0.0001)$ (figure 4$)$. Without cover, all twometer-high biomass piles achieved a moisture content under $30 \%$, while no one-meter-high biomass piles achieved a moisture content under $35 \%$.

\section{DISCUSSION}

This study refers to the drying of whole trees of $A$. melanoxylon, with diameters at breast height of 3 to 12 centimeters, stored on terrain, outside the cover of trees, as the wind and sun conditions are limited within the forest (Kofman and Kent 2009ab, Filbakk et al. 2011). The goal was to achieve desirable moisture content under $30 \%$ (wet basis), in the context of woodchip supply chain for central heating systems, district heating systems and CHP plants in south-central Chile. Results indicate that the natural drying of biomass in the province of Valdivia presents a strong seasonal component, related mainly to the high concentration of precipitation in the winter season. This coincides with other studies conducted in climates characterized by high rainfall, where the drying period is reduced to the summer season (Kofman and Kent 2009ab, Brand et al. 2011, Filbakk et al. 2011, Nord-Larsen et al. 2011). Although precipitation during the year under study was higher than that of the previous year, it was similar to the average of the last decade, however an increase in the level of summer precipitation was presented (table 1). Therefore, the precipitation of the year in which the study was performed can be considered as normal for the reality of the province of Valdivia for the last decade.

In this study, all the biomass felling at the beginning of January (2012) reached moisture content under $30 \%$ at the end of the summer period at the beginning of April, after 94 days of exposure on the ground. However, higher fluctuations in moisture content were observed in piles without cover, coinciding with occasional summer rains. 
Table 1. Monthly precipitation during the trial and comparison with the last period and decade.

Precipitación mensual durante el ensayo y comparación con la última década.

\begin{tabular}{|c|c|c|c|}
\hline \multirow{2}{*}{ Monthly average } & \multicolumn{3}{|c|}{ Precipitation (mm) } \\
\hline & $2001-2010$ & 2011 & $2012 *$ \\
\hline January & 51 & 68 & 66 \\
\hline February & 42 & 33 & 123 \\
\hline March & 77 & 119 & 47 \\
\hline April & 130 & 148 & 58 \\
\hline May & 258 & 169 & 302 \\
\hline June & 363 & 259 & 392 \\
\hline July & 318 & 246 & 235 \\
\hline August & 291 & 289 & 295 \\
\hline September & 136 & 272 & 114 \\
\hline October & 146 & 74 & 55 \\
\hline November & 113 & 71 & 27 \\
\hline December & 71 & 31 & 206 \\
\hline Total year & 1.996 & 1.777 & 1.919 \\
\hline
\end{tabular}

Source: DGA (2015). *Santa Rosa Experimental Weather Station data $\left(39^{\circ} 45^{\prime} 30^{\prime \prime} \mathrm{S}-73^{\circ} 14^{\prime} 55^{\prime \prime} \mathrm{O}\right)$, Universidad Austral de Chile (year 2012).

During the winter, the covered piles of biomass only raised slightly moisture content, at a level usually under $30 \%$. Then, during the spring, the moisture content decreased again to a stable level below $25 \%$ since beginning of November. In the piles without cover, moisture content increased significantly during the winter. However the drying curves were different depending on the height of stacking. Two-meter-high piles were less sensitive to occasional rains presented between January and March, therefore reached moisture content similar to that of the piles with cover at the end of summer. Later, in winter, without cover the two-meter-high piles recovered moisture content, although it did not exceed $40 \%$. Afterwards, during the spring it decreased again to less than $30 \%$. On the other hand, one-meter-high piles were more sensitive to occasional summer rains, which made it difficult to reach stable moisture contents under $30 \%$ from January to March. In addition, during the winter, these piles recovered and even exceeded the initial moisture content. During the spring decreased again, nevertheless, did not reach values below $30 \%$. This may be because the heighted piles increases the proportion of biomass inside the pile, since the top of the uncovered pile is more exposed to rainfall, causing a superior variation in moisture content (Filbakk et al. 2011, Röser et al. 2011).

Results indicate that to obtain wood chips with desired moisture content below $30 \%$ also during winter season, the use of cover is fundamental. In this sense, the type of cover used had a good performance since it fulfilled its function of isolation during the winter without affecting the speed of drying during the summer season. This cover is located in the local market at proximately USD 170 for an area to be covered of $125 \mathrm{~m}^{2}$ and can be used for two drying periods of one year each, implying a cost of capital inferior to one dollar per square meter of cover. Wetzel et al. (2017) determined that after six months of exposure to sun, rain, wind and snow, the plastic-based tarps retained their waterproof properties and remained intact all around the piles, meanwhile the paper-based tarp showed signs of severe degradation and in some locations had completely lost their protective value.

If biomass is stored during the summer season, it is not necessary to use a cover, provided that the biomass be stored at, at least, two meters of height and that the exposure on the ground extends, at least, throughout the summer. If it is not possible to store biomass in piles of at least two meters of height, as occurs when skidding with oxen, to store biomass in piles of 1.5 meters, which can be achieved using oxen, would be the simplest and most economic method. However, the use of semi-permeable cover during the summer allowed stable moisture content to be less than $30 \%$ at the end of summer in one-meter-high piles. The cover also makes possible the supply of biomass during the winter season. Thus, the hypothesis proposed for this study is not rejected.

On the other hand, Kofman and Kent (2009ab) recommend not storing the wood in the forest during two full summer periods, because the energy gain is reduced from one period to another product of the degradation by fungi, with the loss of the integrity of the material. In this study, rot losses were not evaluated. However it was observed that the piles lost all the leaves after the first four months of storage, which led to a significant reduction in the height of the pile, although the stems in general did not show signs of rotting after a year of storage. Erber and Kühmaier (2017), based on a literature review about research trends in European forest fuel supply chains, determined that dry matter losses related to microbial activity during storage of biomass is $1 \%$ to $4 \%$ per year.

This study should be considered as a case study, whose application is for these conditions, mainly associated with the climate and the characteristics of forest biomass. Therefore, in the future, further research and development of different trials could contribute to more knowledge of the potential of the natural drying for different kinds and size of biomass, climatic conditions and cutting periods, as support in the development of a biomass supply chain for energy use. Finally, it is recommended in this future research to incorporate dry matter losses related to microbial activity during storage, and other relevant parameters for graded wood chips according to International Standard EN ISO 17225-4 (2014), as: bulk density, particle size distribution, fines content and ash content. 


\section{CONCLUSIONS}

Under the climate conditions of the province of Valdivia, it is possible to reduce the initial moisture content of small whole trees stored in the field at the beginning of January by more than $15 \%$ after 40 days. Consequently, it is possible to obtain a biomass feedstock with moisture content lower than $30 \%$ at the end of summer. The storage in two-meter-high piles allows reinforcing this result in piles without cover. The use of cover is essential only in cases where it is necessary to have biomass with acceptable moisture content during the winter season, also the use of cover allows reducing moisture content of biomass to a stable level below $25 \%$ before the following summer season.

The results obtained in this study indicate that natural drying is a feasible method under the climate condition of the province of Valdivia, to obtain desirable moisture content for the supply of wood chip for medium and large-scale power plants. Also, for more demanding requirements, it is feasible to use the natural drying as pretreatment to reduce thermal drying energy costs. Natural drying methods can apply operationally in a supply chain configuration based on chipping to the roadside method.

\section{ACKNOWLEDGMENTS}

Study Funded by FONDEF B09I1007 (CONICYT), Chile. The authors are grateful to Robert Brümmer for providing weather data from Santa Rosa Experimental Weather Station of Universidad Austral de Chile.

To the Forest Experimental Center (CEFOR UACh) and in particular to the forest technician Mr. Julián Vázquez for his valuable collaboration in the field work. Also to the Forest Engineers Mr. Daniel Gárate and Mr. José Sandoval for their valuable support in data collection.

\section{REFERENCES}

Alakangas E, M Virkkunen. 2007. Biomass fuel supply chains for solid biofuels. From small to large scale. Jyväskylä, Finland. Finnish Ministry of Employment and the Economy, EUBIONET2. 32 p.

Ananias RA, J Ulloa, DM Elustondo, C Salinas, P Rebolledo, C Fuentes. 2012. Energy consumption in industrial drying of radiata pine. Drying Technology 30(7): 774-779.

Brand MA, GI Bolzon de Muñíz, W Ferreira, JO Brito. 2011. Storage as tool to improve Wood fuel quality. Biomass and Bioenergy 35 : $2581-2588$

DGA (Dirección General de Aguas, CL). 2015. Official information Hydrometeorological and Water Quality online. Consulted 25 Dec. 2015. Available in http://snia.dga.cl/BNAConsultas/reportes; 2015. Llancahue station, Valdivia province, Los Ríos region.

Donoso C. 2008. Ecología Forestal: el bosque y su medio ambiente. Sexta edición. Santiago, Chile. Editorial Universitaria. 372 p.
Egger C, C Öhlinger, B Auinger, B Brandstätter, N Richler, G Dell. 2012. Biomass heating in Upper Austria. Green energy, green jobs. Linz, Austria. OO Energiesparverband. 39 p.

EN ISO 17225-4. (2014). Fuel Specifications and Classes. Part 4: Graded wood chips; ISO: Geneva, Switzerland.

Erber G, M Kühmaier. 2017. Research trends in European forest fuel supply chains: a review of the last ten years (2007-2017). Part one: harvesting and storage. Croatian Journal of Forest Engineering: Journal for Theory and Application of Forestry Engineering 38(2): 269-278.

Filbakk T, O Hoibo, J Nurmi. 2011. Modelling natural drying efficiency in covered and uncovered piles of whole broadleaf trees for energy use. Biomass and bioenergy 35:454-463.

Kaltschmitt M, H Hartmann, H Hofbauer. 2016. Energie aus biomasse. Grundlagen, techniken und verfahren. 3 ed. Berlin, Germany. Springer Vieweg. 1897 p.

Kizha A, HS Han. 2017. Moisture content in forest residues: An insight on sampling methods and procedures. Current Forestry Reports 3(3): 202-212.

Kofman PD, T Kent. 2009a. Long term storage and seasoning of conifer energy wood. Consulted Apr. 12, 2015. Available in http://www.woodenergy.ie/documentspublications/cofordconnectsnotes/

Kofman PD, T Kent. 2009b. Storage and seasoning of conifer roundwood in the forest. Consulted Apr. 12, 2015. Available in http:// www.woodenergy.ie/documentspublications/cofordconnectsnotes/

Kofman PD, T Kent. 2009c. Storage and seasoning of conifer and broadleaf firewood. Consulted Apr. 12, 2015. Available in http:/www. woodenergy.ie/documentspublications/cofordconnectsnotes/

Marcoullier D, S Anderson. 1989. Firewood: How to obtain, measure, season and burn. Stillwater, USA. Oklahoma Cooperative Extension Service Factsheet. No. 9440. 6 p.

Nord-Larsen T, A Bergstedt, O Farver, N Heding. 2011. Drying of firewood - the effect of harvesting time, tree species and shelter of stacked wood. Biomass and Bioenergy 35: 2993-2998.

Palmer D, I Tubby, G Hogan, W Rolls. 2011. Biomass heating: a guide to medium scale wood chip and wood pellet systems. Farnham, UK. Biomass Energy Centre, Forest Research. 20 p.

Pari L, V Civitarese, A del Giudice, AAssirelli, R Spinelli, E Santangelo. 2013. Influence of chipping device and storage method on the quality of SRC poplar biomass. Biomass and Bioenergy 51:169-176.

R Core Team. 2013. R: a language and environment for statistical computing. R Foundation for Statistical Computing. Vienna, Austria. Available in https://www.R-project.org/

Rabe A. 2003. Tyvek, aislante hidrófugo. Consulted Apr. 12, 2012. Available in http://www.rabe-web.com/prod_tyvek.asp

Richardson J, R Bjorheden, P Hakkila, AT Lowe, CT Smith. 2002. Bioenergy from Sustainable Forestry: Guiding Principles and Practice. Dordrecht, The Netherlands. Kluwer Academic Publishers, Forestry Sciences. Vol.71. 344 p.

Röser D, B Mola-Yudego, L Sikanen, R Prinz, D Gritten, B Emer, K Väätäinen, A Erkkilä. 2011. Natural dying treatments during seasonal storage of Wood for bioenergy in different European locations. Biomass and Bioenergy 35(10): 4238-4247.

Wetzel S, S Volpe, J Damianopoulos, S Krigstin. 2017. Can biomass quality be preserved through tarping comminuted roadside biomass piles? Forests 8(9): 305-317. 